\title{
Sputum eosinophils and exhaled nitric oxide during late asthmatic reaction in patients with western red cedar asthma
}

\author{
H. Obata, M. Dittrick, H. Chan, M. Chan-Yeung
}

Sputum eosinophils and exhaled nitric oxide during late asthmatic reaction in patients with western red cedar asthma. H. Obata, M. Dittrick, H. Chan, M. Chan-Yeung. (C)ERS Journals Ltd 1999.

ABSTRACT: Examination of sputum for eosinophils and measurement of exhaled nitric oxide have been proposed as noninvasive methods of assessing airway inflammation in asthma. The use of these tests in the evaluation of patients with occupational asthma has not been reported.

This study investigated the changes in sputum eosinophils and exhaled NO before and at intervals after inhalation challenge with plicatic acid in patients with suspected western red cedar asthma. Of 17 subjects who underwent challenge, nine had a positive bronchoconstrictor reaction (responders) and eight had a negative reaction (nonresponders).

At 6 and $24 \mathrm{~h}$ after plicatic acid challenge, there was a significant increase in sputum eosinophils among responders, which was inversely related to the fall in forced expiratory volume in one second (FEV1) at $6 \mathrm{~h}$. An increase in sputum eosinophils was also found in three nonresponders. Levels of exhaled NO increased at $24 \mathrm{~h}$ after challenge with plicatic acid in both responders and nonresponders, being significant only in nonresponders. No correlation was found between the increase in nitric oxide and the magnitude of the functional changes in the airways. There were significant correlations between the degree of sputum eosinophilia and the level of exhaled NO before and after methacholine and plicatic acid challenge.

In conclusion, the late asthmatic reaction induced by plicatic acid in patients with western red cedar asthma is associated with an increase in sputum eosinophils. The usefulness of measuring sputum eosinophils and exhaled nitric oxide in the clinical evaluation of patients with suspected occupational asthma caused by low molecular weight compounds has yet to be determined.

Eur Respir J 1999; 13: 489-495.

Western red cedar (Thuja plicata) asthma is a paradigm of occupational asthma induced by low molecular weight (MW) compounds. It has been shown to be caused by plicatic acid (MW $440 \mathrm{Da}$ ), which is present in cedar dust [1]. The mechanism of western red cedar asthma is not entirely clear. Isolated late or biphasic asthmatic reactions occur in the majority of patients upon inhalation challenge testing with plicatic acid [2].

A previous study showed an increase in eosinophils in bronchoalveolar lavage (BAL) fluid at 12-24 h after inhalation challenge with plicatic acid in patients with western red cedar asthma who developed a late asthmatic reaction [3]. BAL is an accepted method for studying airway inflammation in asthma. Although it is safe, it is an invasive procedure. Most subjects are reluctant to participate in studies of serial changes in the airways when repeated bronchoscopy is required. Recently, examination of induced sputum has been shown to be a useful noninvasive method for studying airway inflammation [4].

Nitric oxide gas, produced by various cells within the respiratory tract, is detectable in the exhaled air $[5,6]$. The

For editorial comments see page 477
Occupational and Environmental Lung Diseases Unit, Respiratory Division, Dept of Medicine, University of British Columbia, Vancouver, Canada.

Correspondence: M. Chan-Yeung

Respiratory Division

Dept of Medicine

University of British Columbia

2775 Heather Street

Vancouver

BC V5Z 3J5

Canada

Fax: 16048754695

Keywords: Exhaled nitric oxide inhalation challenge occupational asthma sputum eosinophils

Received: June 191998

Accepted after revision November 81998

Supported by the British Columbia Lung Association concentration of exhaled NO is increased in patients with airway inflammation such as asthma [7]. Measurement of exhaled NO is noninvasive and may be a good marker of airway inflammation $[8,9]$.

The purpose of this study was to describe and relate changes in sputum eosinophils and exhaled NO before and at intervals after inhalation challenge testing in patients suspected of suffering from western red cedar asthma and to determine whether these changes reflect functional changes in the airways.

\section{Subjects and methods}

\section{Subjects}

Seventeen consecutive patients referred to the Respiratory Clinic at the University of British Columbia were invited to take part in this study. All subjects were sawmill workers or carpenters who developed symptoms of cough, wheeze and chest tightness after working for at least 6 months with western red cedar. They were all nonsmokers or exsmokers. The majority were still working at the time of evaluation. Three had been away from work for $>1$ 
month, the longest duration being 3 months. Two subjects were taking inhaled steroids at the time of the study.

The subjects were told to refrain from taking inhaled bronchodilators for at least $6 \mathrm{~h}$ and oral bronchodilators for $12 \mathrm{~h}$ before inhalation testing. The same dose of inhaled steroids was used throughout the duration of testing for those who were using them.

\section{Study protocol}

On day 1 , the patients underwent a questionnaire interview, allergy skin testing with common allergens and a methacholine challenge test. Sputum induction was carried out before and $6 \mathrm{~h}$ after the methacholine challenge test. Forced expiratory volume in one second (FEV1), peak expiratory flow (PEF) and exhaled NO were measured before and at hourly intervals for $6 \mathrm{~h}$ after the methacholine challenge test. On each occasion, spirometry was conducted before the measurement of exhaled NO and no bronchodilator was given before the measurement of exhaled NO. The patients continued to monitor their own PEF hourly at home until bedtime.

On day 2, specific challenge testing with plicatic acid in increasing concentrations was carried out. Sputum induction was carried out before and $6 \mathrm{~h}$ after the plicatic acid challenge test. FEV1, PEF and exhaled NO were measured before and at hourly intervals for $6 \mathrm{~h}$ after the plicatic acid challenge test. Hourly monitoring of PEF was carried out by the patients until bedtime.

On day 3, measurement of exhaled NO, a methacholine challenge test and sputum induction were repeated at $24 \mathrm{~h}$ after the plicatic acid challenge test.

The study was conducted over a period of 3 consecutive days. Thus, day 2 prechallenge results represented the 24-h sputum and exhaled NO after methacholine. During each morning and at $6 \mathrm{~h}$ after challenge, the sequence of testing was as follows: spirometry, measurement of exhaled NO, sputum induction, followed by inhalation challenge test. The methacholine challenge test on day 1 with observation for $24 \mathrm{~h}$ was considered an adequate control day since the majority of patients with red cedar asthma have either an isolated late asthmatic reaction or a dual reaction after challenge, while an isolated immediate asthmatic reaction is uncommon. No late asthmatic reactions to the methacholine challenge test have been observed in the authors' laboratory.

The study was approved by the Ethics Committee of the University of British Columbia and informed consent was obtained from each subject.

\section{Methods}

Allergy skin tests. Allergy tests were carried out using the skin prick method with the following common allergens: feather, house dust, two house dust mite allergens, mixed Pacific grass, tree and weed pollen, alternaria, cladosporium, two aspergillus allergens, cat, dog and horse dander, and four common food allergens (Bencard Allergy Laboratory, Mississauga, Ontario, Canada). Normal saline and histamine $1 \mathrm{mg} \cdot \mathrm{mL}^{-1}$ were used as a negative and a positive control, respectively. The results were read at $15 \mathrm{~min}$ after testing and the largest weal diameter and its perpendicular were read and averaged. A skin test was considered positive if the average diameter of the weal was $\geq 3 \mathrm{~mm}$ more than the nega- tive control. A patient was considered atopic when he or she had one or more positive skin test reactions.

Methacholine challenge test. Methacholine (Methapharm, Brantford, Ontario, Canada) inhalation tests were carried out using the tidal breathing method as described previously [10]. In brief, the diluent control solution and solutions of methacholine were aerosolized in a BennettTwin nebulizer (Puritan-Bennett Corporation, Carlsbad, $\mathrm{CA}$, USA) with oxygen at a flow rate of $5 \mathrm{~L} \cdot \mathrm{min}^{-1}$. The output of the nebulizer was $0.24 \mathrm{~mL} \cdot \mathrm{min}^{-1}$. The patients inhaled the solutions at tidal breathing for $2 \mathrm{~min}$ starting with the diluent, followed by increasing concentration of methacholine at intervals of $5 \mathrm{~min}$. FEV1 and forced vital capacity (FVC) were measured before the test and at $30 \mathrm{~s}$ and $4 \mathrm{~min}$ after each inhalation. The provocative concentration of methacholine causing a $20 \%$ fall in FEV1 (PC20) was obtained by interpolation of the last two points of the dose-response curve drawn on a semi-logarithmic noncumulative scale. A PC20 of $\leq 8 \mathrm{mg} \cdot \mathrm{mL}^{-1}$ was considered a positive methacholine challenge.

Plicatic acid challenge test. The method used for the specific challenge with plicatic acid has been described previously [2]. Increasing concentrations of plicatic acid were given by inhalation through a Bennett-Twin nebulizer for $2 \mathrm{~min}$ at tidal breathing, similar to the protocol used in the methacholine challenge test. A positive reaction was defined as a fall in FEV1 or PEF of $>20 \%$ from the baseline at any time after the challenge. When the changes in FEV1 or PEF were $<20 \%$ from the baseline, a change in $\mathrm{PC}_{20}$ of greater than four-fold was required for the late reaction to be considered positive. Immediate reactions occurred within a few minutes, while late reactions occurred $2-12 \mathrm{~h}$ after challenge.

Measurement of exhaled nitric oxide. Exhaled NO was measured by a rapid-response chemiluminescent method using the Sievers 280 NOA analyser (Sievers, Boulder, CO, USA), with sensitivity from 5 to 500,000 parts per billion (ppb) according to SILKOFF et al. [11]. In brief, the subject, with no noseclip, inhaled through the mouth to total lung capacity (TLC) and immediately exhaled. During exhalation, the subject was asked to maintain a constant mouth pressure for a period of $10-15 \mathrm{~s}$ of 2.7 $\mathrm{kPa}(20 \mathrm{mmHg})$, which was displayed on the pressure monitor, and to support his or her cheeks manually to achieve a good mouthpiece seal and ensure vellum closure. NO was sampled via a sideport close to the mouth. $\mathrm{NO}$ and mouth pressure signals were simultaneously shown on a computer display. The endpoint for the measurement was defined when a plateau of $\geq 5 \mathrm{~s}$ duration was reached. Repeated exhalations were recorded to give three values of NO plateau within $10 \%$. A rest of $30 \mathrm{~s}$ was allowed between exhalations. Calibration of the analyser was carried out each day with zero NO gas and 50 parts per million (ppm) NO before use. Exhaled NO was measured in the laboratory in nine normal, healthy subjects with normal lung function and negative methacholine challenge test and the geometric mean was $22.9 \mathrm{ppb}$ (range 5.5-56.4 ppb). 
Table 1. - Clinical characteristics of the study subjects

\begin{tabular}{|c|c|c|c|c|c|c|c|c|}
\hline \multirow[b]{2}{*}{$\begin{array}{l}\text { Subject } \\
\text { No. }\end{array}$} & \multirow[b]{2}{*}{$\begin{array}{l}\text { Age } \\
\text { yrs }\end{array}$} & \multirow[b]{2}{*}{$\begin{array}{l}\text { Duration of } \\
\text { exposure } \\
\text { months }\end{array}$} & \multirow[b]{2}{*}{$\begin{array}{l}\text { Duration of } \\
\text { symptoms } \\
\text { months }\end{array}$} & \multirow[b]{2}{*}{ Atopy } & \multicolumn{2}{|c|}{ Baseline } & \multirow[b]{2}{*}{$\begin{array}{c}\text { Maximal } \\
\text { change in } \\
\text { FEV }^{*} \% \text { fall }\end{array}$} & \multirow[b]{2}{*}{$\begin{array}{c}\mathrm{PC} 20 \\
\mathrm{mg} \cdot \mathrm{mL}^{-1} \\
24 \mathrm{~h}^{\#}\end{array}$} \\
\hline & & & & & $\begin{array}{c}\text { FEV1 } \\
\% \text { pred. }\end{array}$ & $\begin{array}{c}\mathrm{PC} 20 \\
\mathrm{mg} \cdot \mathrm{mL}^{-1}\end{array}$ & & \\
\hline \multicolumn{9}{|c|}{ Responders } \\
\hline \multicolumn{9}{|c|}{ Isolated immediate } \\
\hline $\begin{array}{l}1 \\
\text { Isolate }\end{array}$ & 30 & 36.0 & 12.0 & - & 111.5 & 4.3 & 17.0 & 3.48 \\
\hline 2 & 40 & 6.0 & 2.0 & + & 111.3 & 3.3 & 26.0 & 0.03 \\
\hline 3 & 57 & 444.0 & 120.0 & + & 87.2 & 6.7 & 20.0 & 2.42 \\
\hline 4 & 26 & 42.0 & 36.0 & + & 72.2 & 1.3 & 28.0 & 0.03 \\
\hline 5 & 20 & 42.0 & 6.0 & - & 98.6 & 6.2 & 30.0 & 1.21 \\
\hline $6^{\dagger}$ & 30 & 12.0 & 2.0 & + & 97.8 & 1.7 & 22.0 & 0.65 \\
\hline \multicolumn{9}{|l|}{ Dual } \\
\hline 7 & 39 & 48.0 & 36.0 & + & 92.1 & 6.4 & 25.0 & 3.08 \\
\hline 8 & 42 & 6.0 & 1.0 & + & 90.9 & 1.3 & 22.0 & 0.03 \\
\hline 9 & 59 & 36.0 & 14.0 & + & 85.6 & 1.1 & 24.0 & 0.91 \\
\hline Mean & 38.1 & 74.7 & 25.4 & & $94.1 *$ & 2.8 & 23.8 & 0.43 \\
\hline SD & 13.3 & 139.5 & 38.0 & & 12.5 & 2.2 & 4.0 & 7.93 \\
\hline \multicolumn{9}{|c|}{ Nonresponders } \\
\hline 10 & 35 & 120.0 & 8.0 & + & 99.8 & 0.4 & 0.0 & 0.71 \\
\hline 11. & 31 & 36.0 & 24.0 & - & 112.8 & $32.0^{\S}$ & 4.0 & $32.00^{\S}$ \\
\hline $12^{\dagger}$ & 36 & 62.4 & 10.0 & - & 102.1 & 2.0 & 6.0 & 2.86 \\
\hline 13 & 32 & 80.4 & 36.0 & - & 110.0 & 19.4 & 6.0 & 21.33 \\
\hline 14 & 21 & 12.0 & 4.0 & + & 106.8 & 1.7 & 13.0 & 1.60 \\
\hline 15 & 26 & 6.0 & 9.0 & + & 114.5 & $32.0^{\S}$ & 5.0 & $32.00^{\S}$ \\
\hline 16 & 39 & 60.0 & 36.0 & + & 89.6 & 4.1 & 11.0 & 8.89 \\
\hline 17 & 31 & 204.0 & 72.0 & + & 96.9 & 13.3 & 4.0 & 29.10 \\
\hline Mean & 32.1 & 72.6 & 24.9 & & 104.1 & 5.9 & 6.1 & 8.2 \\
\hline SD & 6.1 & 64.7 & 22.9 & & 8.5 & 5.1 & 4.1 & 4.6 \\
\hline
\end{tabular}

FEV1: forced expiratory volume in one second; PC20: provocative concentration of methacholine causing a $20 \%$ fall in FEV1. ${ }^{\dagger}$ : Taking inhaled steriods $400 \mathrm{mg} \cdot \mathrm{day}^{-1}$ up to the day before challenge; ${ }^{*}$ : during late asthmatic reaction; ${ }^{\#}: 24 \mathrm{~h}$ after plicatic acid challenge. §: For PC20 $>32 \mathrm{mg} \cdot \mathrm{mL}^{-1}$, in the calculation a value of $33 \mathrm{mg} \cdot \mathrm{mL}^{-1}$ was assigned, and for those whose FEV 1 dropped by $>10 \%$ after saline, a PC20 of $0.03 \mathrm{mg} \cdot \mathrm{mL}^{-1}$ was assigned. $*$ : p $<0.05$, significant difference between responders and nonresponders (unpaired t-test).

Sputum induction. Sputum was induced with an aerosol of inhaled hypertonic saline using a modification of the method of PIN et al. [12]. FEV1 and FVC were measured three times before induction. The best FEV1 value was used as the baseline. A Fisoneb ultrasonic nebulizer (Clement Clarke International, Harlow, Essex, UK) with an output of $0.87 \mathrm{~mL} \cdot \mathrm{min}^{-1}$ and aerodynamic mass median diameter of $5.58 \mathrm{~mm}$ was used. Concentrations of saline at $0.85-3.4$ and 5\%, each for $7 \mathrm{~min}$, were administered by inhalation through a mouthpiece without a valve or noseclip. After each inhalation period, spirometry was repeated. The patients were then asked to rinse their mouths with water and blow their noses (to reduce contamination of the sputum specimen with saliva and postnasal drip) before coughing sputum into a container. The nebulization was stopped when a good quality sputum sample was obtained. If the FEV1 fell by $>10 \%$ from the baseline the same concentration of saline was used for the next inhalation. If the FEV1 fell by $>20 \%$ or if troublesome symptoms occurred, nebulization was discontinued.

Sputum examination. Sputum was collected in a sterile container and analysed within $2 \mathrm{~h}$ using the method of Pizzichini et al. [13]. The whole sample of sputum was transferred to a Petri dish. The weight and macroscopic characteristics of the sample were recorded. All vis- ible portions of sputum with little or no squamous cell contamination were carefully selected, placed in a preweighed conical tube and weighed. Freshly prepared dithiothreitol (DTT) (Spitolysin; Calbiochem, San Diego, $\mathrm{CA}$, USA), at a dilution of 1:10 $\left(10 \mathrm{mg} \cdot \mathrm{mL}^{-1}\right)$, was added in a volume (in $\mu \mathrm{L}$ ) equal to four-times the weight of sputum (in $\mathrm{mg}$ ), mixed by vortex for $15 \mathrm{~s}$ and rocked on bench rocker for $15 \mathrm{~min}$. It was then mixed with an equal volume of Dulbecco's phosphate-buffered saline (D-PBS), rocked for another $5 \mathrm{~min}$ and filtered through $48-\mu \mathrm{m}$ nylon gauze. The suspension was spun at $790 \times g$ for $10 \mathrm{~min}$ and the supernatant aspirated. The pellet was resuspended in a volume of $500-1,000 \mu \mathrm{L}$ of D-PBS. The total cell count was determined using a Neubauer haemocytometer and the number of cells $\mathrm{mL}^{-1}$ of the processed sputum calculated. The viability of cells was evaluated by the trypan blue exclusion method. The cell suspension was adjusted to $1 \times 10^{6}$ cells $\cdot \mathrm{mL}^{-1}$. Two cytospins (each coded) were prepared by placing $75 \mu \mathrm{L}$ of cell suspension in cytocentrifuge cups and spinning at $300 \times g$ for $5 \mathrm{~min}$. The slides were air-dried and stained using Wright stain. Four hundred nonsquamous cells were counted in the selected portion by two investigators blinded to the clinical status of the subjects. The nonsquamous differential cell counts were expressed as a percentage of the total nonsquamous counts. 
Table 2. - Exhaled nitric oxide and cells in sputum

\begin{tabular}{|c|c|c|c|c|c|c|c|}
\hline \multirow[b]{2}{*}{$\begin{array}{l}\text { Subject } \\
\text { No. }\end{array}$} & \multirow[b]{2}{*}{$\begin{array}{c}\text { Exhaled NO } \\
\text { ppb }\end{array}$} & \multicolumn{6}{|c|}{ Cells in Sputum } \\
\hline & & TCC & $\begin{array}{c}\text { Eos } \\
\%\end{array}$ & $\begin{array}{c}\mathrm{Neu} \\
\%\end{array}$ & $\underset{\%}{\mathrm{Mac}}$ & $\underset{\%}{\operatorname{Lymph}}$ & $\begin{array}{c}\text { Epi } \\
\%\end{array}$ \\
\hline \multicolumn{8}{|c|}{ Responders } \\
\hline 1 & 39.7 & 15.2 & 3.0 & 83.5 & 8.0 & 0.8 & 0.2 \\
\hline 2 & 60.4 & 1.7 & 15.0 & 37.6 & 47.2 & 0.0 & 0.0 \\
\hline 3 & 45.6 & 7.3 & 4.5 & 64.7 & 28.1 & 0.2 & 1.6 \\
\hline 4 & 13.2 & 2.1 & 1.4 & 18.8 & 76.2 & 0.0 & 3.6 \\
\hline 5 & 31.7 & 1.9 & 1.7 & 2.3 & 96.0 & 0.0 & 0.0 \\
\hline 6 & 60.6 & 2.0 & 2.8 & 7.7 & 89.2 & 0.0 & 0.3 \\
\hline 7 & 43.1 & 1.3 & 5.7 & 26.5 & 68.3 & 0.7 & 0.0 \\
\hline 8 & 28.5 & 1.1 & 0.0 & 42.9 & 56.6 & 0.5 & 0.0 \\
\hline 9 & 94.2 & 1.1 & 12.4 & 32.9 & 35.2 & 0.2 & 19.3 \\
\hline Mean $^{\dagger}$ & 40.9 & 2.4 & 3.5 & 23.9 & 46.5 & 0.2 & 1.0 \\
\hline $\mathrm{SD}^{\dagger}$ & 1.8 & 2.5 & 2.4 & 3.1 & 2.1 & 1.3 & 2.8 \\
\hline \multicolumn{8}{|c|}{ Nonresponders } \\
\hline 10 & 32.0 & 0.3 & 1.1 & 32.5 & 65.0 & 0.9 & 0.4 \\
\hline 11 & 14.5 & 1.3 & 0.5 & 43.1 & 55.3 & 0.1 & 1.0 \\
\hline 12 & 74.8 & 4.3 & 20.7 & 71.6 & 6.7 & 0.0 & 1.0 \\
\hline 13 & 24.2 & 1.0 & 0.6 & 82.0 & 16.9 & 0.0 & 0.5 \\
\hline 14 & 131.7 & 1.7 & 60.0 & 11.6 & 28.0 & 0.0 & 0.4 \\
\hline 15 & 22.3 & 0.8 & 0.0 & 3.0 & 77.3 & 0.2 & 19.5 \\
\hline 16 & 22.2 & 1.7 & 0.0 & 50.0 & 50.0 & 0.0 & 0.0 \\
\hline 17 & 33.7 & 0.4 & 5.3 & 58.7 & 34.3 & 0.0 & 1.7 \\
\hline $\operatorname{Mean}^{\dagger}$ & 34.1 & 1.0 & 2.8 & 30.9 & 33.7 & 0.1 & 1.3 \\
\hline $\mathrm{SD}^{\dagger}$ & 2.1 & 2.3 & 4.7 & 3.8 & 2.2 & 1.3 & 2.6 \\
\hline
\end{tabular}

TCC: total cell count $\left(\times 10^{6} \cdot \mathrm{mm}^{-3}\right)$; Eos: eosinophils; Neu: neutrophils; Mac: macrophages; Lymph: lymphocytes; Epi: epithelial cells; ppb: parts per billion. ${ }^{\dagger}$ : Geometric mean and SD.

\section{Statistical analysis}

Data that were not normally distributed were transformed to natural logarithms before analysis. These included PC20, level of exhaled NO, and total and differential cell counts. Data at baseline, 6 and $24 \mathrm{~h}$ after challenge were compared between groups using unpaired t-tests or Chi-squared tests. Prechallenge and postchallenge data (methacholine and plicatic acid) were compared within groups using repeated-measures analysis of variance [14]. Pairwise comparison between different times was used to supplement the results and Bonferroni's correction for multiple comparison was applied to the pvalues. Pearson correlations were carried out using the logarithmically transformed data.

\section{Results}

\section{Characteristics of study subjects}

Of the 17 patients, nine had a positive reaction to plicatic acid challenge testing (responders). One had an isolated immediate reaction, five an isolated late reaction and three a biphasic reaction. Eight patients did not respond to plicatic acid challenge testing (nonresponders).

The characteristics of the study subjects are shown in table 1. All were male and nonsmokers, with the exception of one exsmoker who was a nonresponder. The majority of the patients were atopic subjects. The mean FEV1 and the PC20 before specific challenge testing were lower in the responder group than in the nonresponder group, but only FEV1 was significantly different. All subjects with a late asthmatic reaction had a fall in FEV1
$>20 \%$. The mean PC20 at $24 \mathrm{~h}$ after challenge with plicatic acid fell significantly from baseline among the responders.

The level of exhaled NO before methacholine challenge tests was negatively correlated with $\mathrm{PC} 20$ among nonresponders $(\mathrm{r}=-0.74, \mathrm{p}=0.035)$ but not among responders.

All subjects, responders and nonresponders were able to produce sputum for analysis at all times. Table 2 shows baseline exhaled NO and cells in induced sputum before inhalation testing. There were no significant differences between levels of exhaled NO, total cell count and differential cell count between the responders and nonresponders. Two subjects in the nonresponder group had very high baseline eosinophilia in the sputum even before challenge (subject Nos. 12 and 14).

\section{Cells in sputum}

Among the responders, there was no significant increase in sputum eosinophils at $6 \mathrm{~h}$ after methacholine challenge. After plicatic acid challenge, they showed a marked rise in the percentage of eosinophils at both 6 and $24 \mathrm{~h}$ (fig. 1). There was a significant inverse correlation between the percentage change in FEV1 and the percentage change in eosinophils at $6 \mathrm{~h}(\mathrm{r}=-0.62, \mathrm{p}<0.05)$ but not at $24 \mathrm{~h}(\mathrm{r}=-0.19, \mathrm{p}=0.51)$ after plicatic acid challenge. There were no significant changes in the total cell count, neutrophils or other cells in the sputum after plicatic acid challenge.

The nonresponders showed no significant changes in the mean percentage of eosinophils after methacholine or plicatic acid challenge, although at $6 \mathrm{~h}$ after plicatic acid 
challenge eosinophils increased in three nonresponders (fig. 1).

No correlation was found between the percentage of eosinophils in the sputum and $\mathrm{PC} 20$ before the methacholine challenge test.

\section{Exhaled nitric oxide}

After methacholine challenge, no change in exhaled NO was found in either responders or nonresponders.

After plicatic acid challenge, there was no significant change in the level of exhaled $\mathrm{NO}$ at $6 \mathrm{~h}$ in either responders or nonresponders. At $24 \mathrm{~h}$ after challenge, exhaled NO increased from baseline in both groups, but the increase was only significant for nonresponders (fig. 2). The three nonresponders who showed an increase in eo-
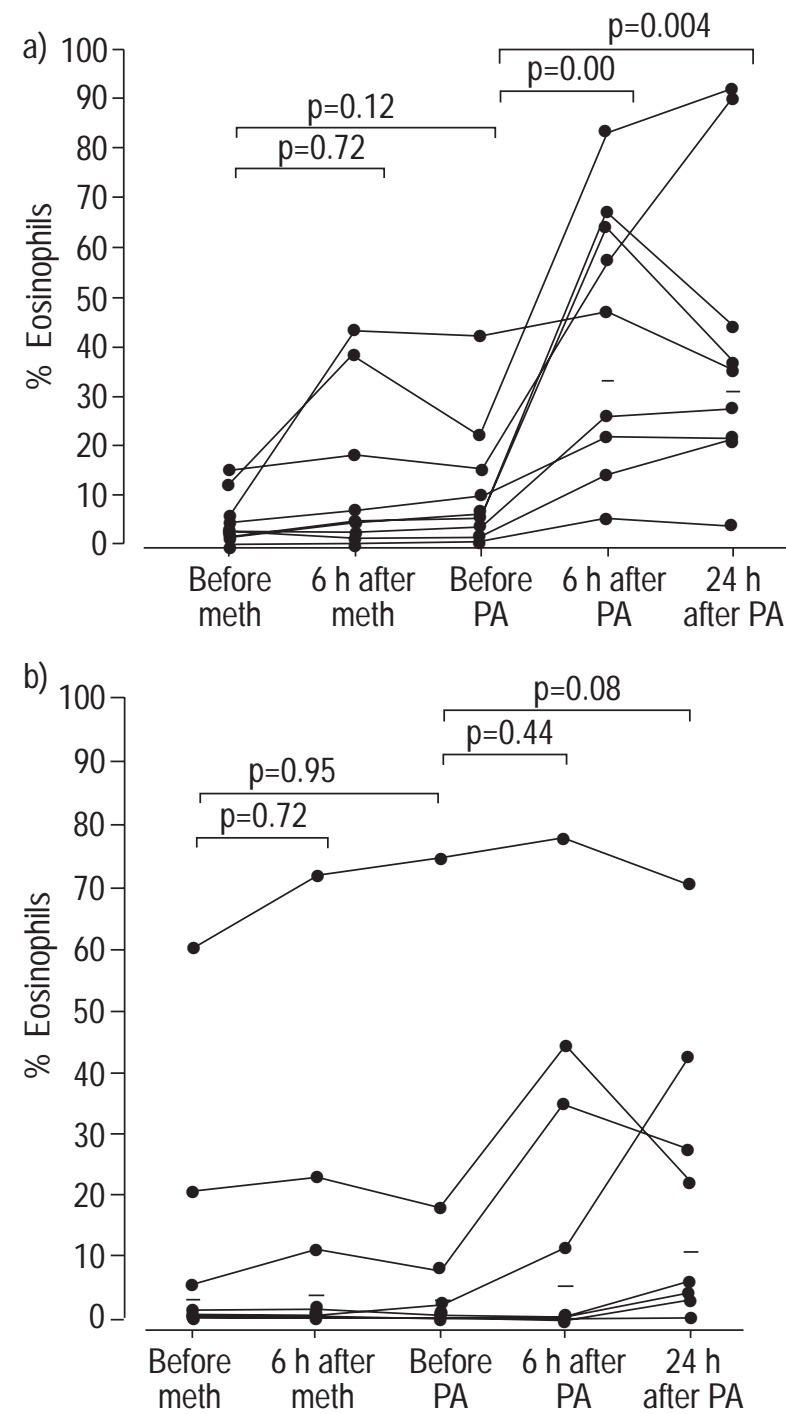

Fig. 1. - Sputum eosinophils (\%) before and at $6 \mathrm{~h}$ after methacholine (meth) challenge; before, 6 and $24 \mathrm{~h}$ after plicatic acid (PA) challenge in a) responders and $b$ ) nonresponders. Repeated-measures analysis of variance showed differences at different times among the responders; $p$ values are based on pairwise comparisons shown on the graph, after Bonferroni's correction for multiple comparisons. Horizontal bars represent subject mean. sinophils at $6 \mathrm{~h}$ after plicatic acid challenge also showed an increase in exhaled NO at the same time. There was no correlation between the maximal recorded changes in FEV1 during the late asthmatic reaction and the maximal recorded changes in exhaled NO.

There were significant correlations between the degree of sputum eosinophilia and the level of exhaled NO before $(\mathrm{r}=0.86, \mathrm{p}<0.001)$ and at $6 \mathrm{~h}(\mathrm{r}=0.7, \mathrm{p}<0.002)$ after methacholine challenge and at every other time before $(\mathrm{r}=0.71$, $\mathrm{p}<0.001)$, at $6 \mathrm{~h}(\mathrm{r}=0.52, \mathrm{p}<0.05)$ and $24 \mathrm{~h}(\mathrm{r}=0.50, \mathrm{p}<0.05)$ after plicatic acid challenge (fig. 3 ). There was, however, no correlation between the percentage changes in exhaled $\mathrm{NO}$ and the percentage changes in sputum eosinophils from baseline at 6 and $24 \mathrm{~h}$ after plicatic acid challenge.

\section{Discussion}

In this study, significant correlations were found between the degree of sputum eosinophilia and the levels
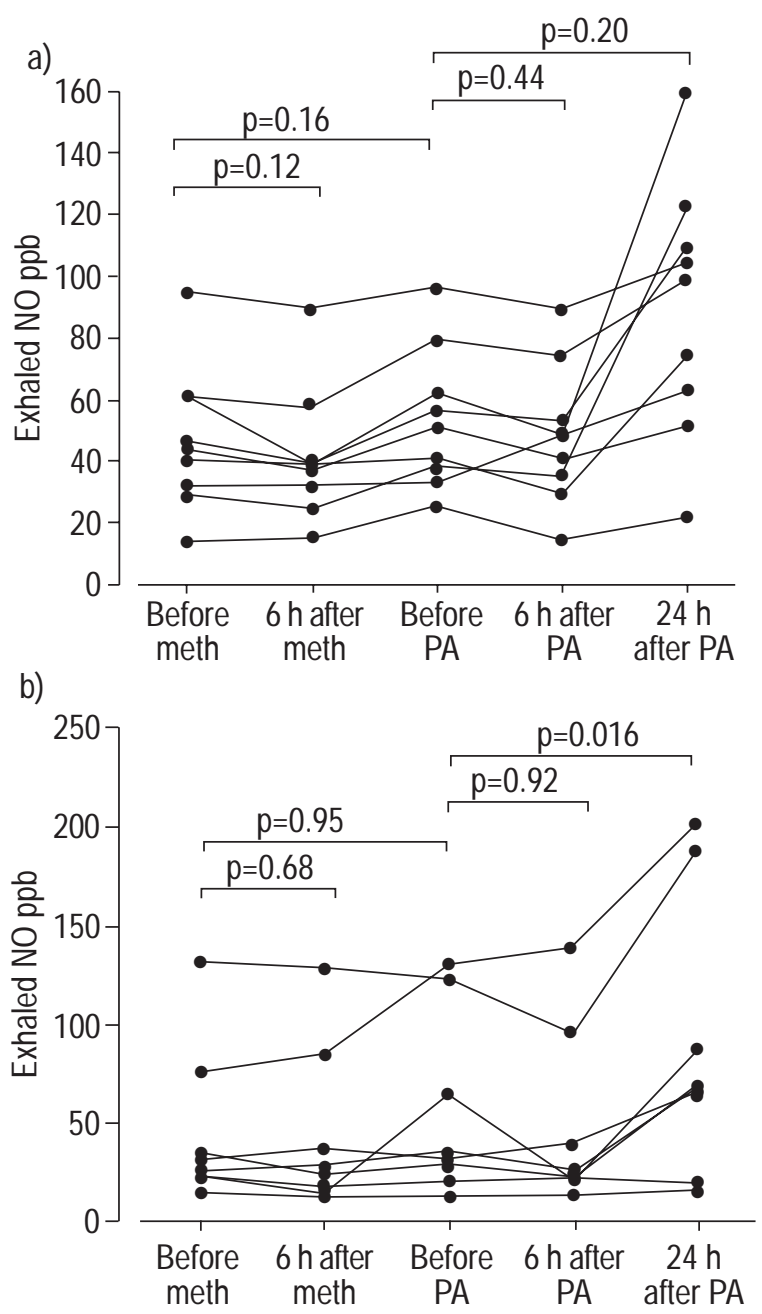

Fig. 2. - Exhaled nitric oxide before and at $6 \mathrm{~h}$ after methacholine (meth) challenge; before, $6 \mathrm{~h}$ and $24 \mathrm{~h}$ after plicatic acid (PA) challenge in a) responders and b) nonresponders. Repeated-measures analysis of variance showed differences at different times among the nonresponders; $p$-values are base on pairwise comparisons shown on the graph, after Bonferroni's correction for multiple comparisons. ppb: parts per billion. 


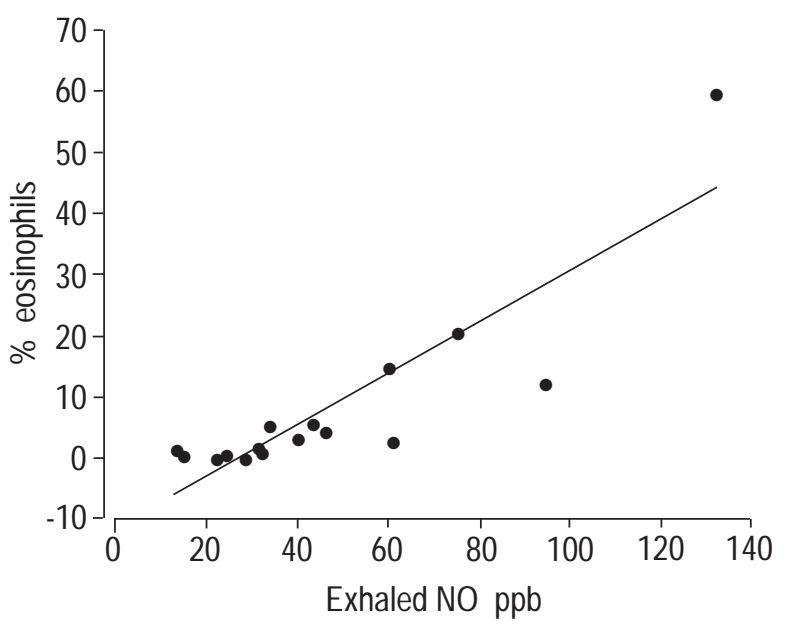

Fig. 3. - Correlation between sputum eosinophils (\%) and exhaled nitric oxide in all study subjects before methacholine challenge $(r=0.86$, $\mathrm{p}<0.001)$. ppb: part per billion.

of exhaled NO at all times before and after inhalation challenge tests with methacholine and plicatic acid, suggesting that the level of exhaled NO reflects the degree of eosinophilic airway inflammation. Moreover, a marked increase in eosinophils in the sputum was demonstrated during and after late asthmatic reaction induced by plicatic acid, confirming the previous finding that plicatic acid induces airway inflammation with a predominance of eosinophils in patients with western red cedar asthma [4]. The changes in sputum eosinophils at $6 \mathrm{~h}$ after plicatic acid challenge correlated with the magnitude of the functional changes in the airways.

Exhaled NO has been shown to be produced endogenously [15]. The concentration of exhaled NO is increased above normal levels in subjects with inflammatory diseases such as asthma [7]. Since corticosteroids have been shown to reduce the level of exhaled NO [8] and exhaled NO correlated with the airway responsiveness in steroidnaive asthmatics [9], it has been postulated that measurement of exhaled NO may be a noninvasive method of assessing airway inflammation. In this study, exhaled NO increased after plicatic acid challenge in both responders and nonresponders, but the increase was only significant in nonresponders. This finding is somewhat puzzling. However, it has been reported that the level of exhaled NO was reduced when measured within $1 \mathrm{~h}$ after spirometry [16]. Moreover, bronchoconstriction reduces exhaled NO measurements, while the use of a bronchodilator increases the level [17]. The failure to show significantly increased levels of exhaled NO after plicatic acid challenge in responders in this study could be explained by the fact that spirometry was always performed before the measurement of exhaled NO during each observation and bronchodilators were not used.

The mechanisms of western red cedar asthma or other types of occupational asthma due to low molecular weight compounds such as isocyanate are not clear. The clinical picture of these conditions is suggestive of an allergic disease. However, specific immunoglobulin E antibodies are found only in a small proportion of the patients proven to have the disease [18]. Specific challenge tests with these compounds induce mostly isolated late asthmatic reactions or dual asthmatic reactions, while with high molecular weight compounds isolated immediate or dual asthmatic reactions and, rarely, isolated late asthmatic reactions are induced [19]. In both western red cedar asthma and isocyanate-induced asthma, bronchial biopsy showed activated eosinophils and activated T-lymphocytes, suggesting that cell-mediated immunity may be involved in the pathogenesis of this condition $[20,21]$.

It has been further postulated that both immunological and nonimmunological mechanisms are likely to be involved in the pathogenesis of these conditions [22]. Plicatic acid has also been shown to induce the release of histamine from basophils of some nonexposed normal subjects [23] and to activate the complement system in vitro [24]. Toluene diisocyanate has been shown to activate the efferent function of capsaicin-sensitive primary afferents [25] and inhibit neutral endopeptidases in experimental animals [26] and in vitro preparations [27], thus activating neurogenic inflammation. These properties are capable of inducing airway inflammation directly and may potentiate the immunological response.

The increase in sputum eosinophils and exhaled NO found in three out of eight nonresponders after challenge with plicatic acid may be due to the direct effect of plicatic acid inducing airway inflammation, even though there were no significant changes in FEV1 or PC20. However, it has been shown recently that the level of exhaled NO is not always increased in those with definite airway inflammation, such as during a viral infection [28].

Atopic asthmatics have been shown to respond with eosinophilic airway inflammation after exposure to nonspecific irritants such as ozone [29]. The exact mechanism for the eosinophilia from ozone exposure is not known. The investigators postulated that atopy rather than asthma per se is necessary for this response to occur and that ozone may induce epithelial cells to produce cytokines that are not only chemotactic factors for neutrophils but also for eosinophils. As two out of the three nonresponders in this study were atopic subjects, the same mechanism may be operating with plicatic acid challenge.

In the present inhalation challenge tests with plicatic acid, doses did not routinely exceed $10 \mathrm{mg} \cdot \mathrm{mL}^{-1}$ nebulized for a period of $2 \mathrm{~min}$. It is quite possible that the three nonresponders with an increase in eosinophils at $6 \mathrm{~h}$ after plicatic acid challenge may have developed a fall in FEV1 of $>20 \%$ if they were challenged with a higher dose of plicatic acid or the same dose for a longer duration.

The results of the present study are somewhat different from those reported by KHARITONOV et al. [30], who found elevated exhaled NO during late asthmatic reaction in those asthmatics who developed one after allergen challenge. They demonstrated that the greater the intensity of the late reaction, the higher the level of exhaled NO during the late reaction. The levels of exhaled NO in the patients in their study were much higher than those observed in the present study, suggesting that the discrepancy could be related to differences in techniques of measurement, types of instrument used to measure exhaled $\mathrm{NO}$, or agents used for challenge testing.

In conclusion, measurement of sputum eosinophils and exhaled nitric oxide is a relatively easy and noninvasive method of assessing the degree of eosinophilic inflammation in the airways. The usefulness of these measurements in the clinical evaluation of patients with occupational 
asthma and, in particular, those due to low molecular weight compounds, needs to be evaluated further owing to the direct inflammatory effects of these compounds on the airways.

Acknowledgemnts. The authors wish to thank F.E. Hargreave and P.E. Silkoff for their advice in making this study possible, J-L Malo for his helpful criticism, and A. DyBuncio for her assistance in data analysis

\section{References}

1. Chan-Yeung M, Barton G, MacLean L, Grzybowski S. Occupational asthma and rhinitis due to western red cedar (Thuja plicata). Am Rev Respir Dis 1973; 108: 10941102.

2. Chan-Yeung M, Lam S, Koerner S. Clinical features and natural history of occupational asthma due to western red cedar (Thuja plicata). Am J Med 1982; 72: 411-415.

3. Lam S, Chan H, LeRiche J, Chan-Yeung M. Cellular and protein change in bronchial lavage fluid following late asthmatic reaction in patients with red cedar asthma. Allergy Clin Immunol 1987; 80: 44-50.

4. Pavord ID, Pizzichini MMM, Pizzichini E, Hargreave FE The use of induced sputum to investigate airway inflammation. Thorax 1997; 52: 498-501.

5. Kobzik L, Bredt DS, Lowenstein CJ, et al. Nitric oxide synthase in human and rat lung: immunocytochemical and histochemical localization. Am J Respir Cell Mol Biol 1993; 9: 371-377.

6. Hamid Q, Springall DR, Riveros-Moreno D, et al. Induction of nitric oxide synthase in asthma. Lancet 1993; 342: 1510-1513.

7. Kharitonov SA, Yates D, Robbins RA, Logan-Sinclair R, Shinebourne EA, Barnes PJ. Increased nitric oxide in exhaled air of asthmatic patients. Lancet 1994; 343: 133 135.

8. Kharitonov SA, Yates DA, Barnes PJ. Inhaled glucocorticoids decrease nitric oxide in exhaled air of asthmatic patients. Am J Respir Crit Care Med 1996; 153: 454-457.

9. Dupont LL, Rochette F, Demedt MG, Verleden GM. Exhaled nitric oxide correlates with airway hyperresponsiveness in steroid-naive patients with mild asthma. Am J Respir Crit Care Med 1998; 157: 894-898.

10. Lam S, Wong R, Chan-Yeung M. Nonspecific bronchial reactivity in occupational asthma. $J$ Allergy Clin Immunol 1979; 63: 28-34.

11. Silkoff PE, McClean PA, Slutsky AS, et al. Marked flowdependence of exhaled nitric oxide using a new technique to exclude nasal nitric oxide. Am J Respir Crit Care Med 1997; 155: 260-267.

12. Pin I, Gibson PG, Kolendowicz R, et al. Use of induced sputum cell counts to investigate airway inflammation in asthma. Thorax 1992; 47: 25-29.

13. Pizzichini E, Pizzichini MMM, Efthimiadis A, Hargreave FE, Dolovich J. Measurement of inflammatory indices in induced sputum: effects of selection of sputum to minimize salivary contamination. Eur Respir $J$ 1996; 9: 1174-1180.
14. Crowder MJ, Hand DJ. Analysis of Repeated Measures. London, Chapman and Hall, 1990.

15. Curran AD. The role of nitric oxide in the development of asthma. Int Arch Allergy Immunol 1996; 111: 1-4.

16. Deykin A, Halpern O, Massaro AF, Drazen JM, Israel E. Expired nitric oxide after bronchoprovocation and repeated spirometry in patients with asthma. Am J Respir Crit Care Med 1998; 157: 769-775.

17. de Gouw HWF, Hendriks J, Woltman AM, Twiss IM, Sterk PJ. Exhaled nitric oxide (NO) is reduced shortly after bronchoconstriction to direct and indirect stimuli in asthma. Am J Respir Crit Care Med 1998; 158: 315-319.

18. Tse KS, Chan H, Chan-Yeung M. Specific IgE antibodies in workers with asthma due to western red cedar. Clin Allergy 1982; 12: 249-258.

19. Chan-Yeung M, Malo J-L. Occupational asthma. N Engl J Med 1995; 333: 107-112.

20. Frew AJ, Chan H, Lam S, Chan-Yeung M. Eosinophil activation and T-lymphocyte phenotype in occupational asthma due to western red cedar. Am J Respir Crit Care Med 1995; 151: 340-373.

21. Mapp CE, Saetta M, Maestrelli P, Ciacia A, Fabbri LM. Low molecular weight pollutants and asthma: pathogenetic mechanisms and genetic factors. Eur Respir $J$ 1994; 7: 1559-1563.

22. Chan-Yeung M. Immunologic and non-immunologic mechanisms in asthma due to western red cedar. J Allergy Clin Immunol 1982; 70: 32-37.

23. Frew A, Chan H, Dryden P, Salari H, Lam S, Chan-Yeung M. Immunologic studies of the mechanisms of occupational asthma caused by western red cedar. J Allergy Clin Immunol 1993; 92: 466-478.

24. Chan-Yeung M, Giclas P, Benson P. Activation of the complement by plicatic acid - the chemical compound responsible for asthma due to western red cedar (Thuja plicata). J Allergy Clin Immunol 1980; 65: 333-339.

25. Mapp C, Chitano P, Fabbri LM, et al. Evidence that toluene diisocyanate (TDI) activates the efferent function of capsaicin-sensitive primary afferent. Eur J Pharmacol 1990; 180: 113-118.

26. Mapp C, Chitano P, Fabbri LM, et al. Pharmacological modulation of the contractile response to toluene diisocyanate in the rat urinary bladder. Br J Pharmacol 1990; 100: 886-888.

27. Mapp C, Graf PD, Boniotti A, Nadel JA. Toluene diisocyanate contracts guinea pig bronchial smooth muscle by activating capsaicin-sensitive sensory nerves. $J$ Pharmacol Exp Ther 1991; 256: 1082-1085.

28. Berlyne G, Silkoff P, Kamada D, Efthimiadis A, Hargreave FE. Exhaled nitric oxide and induced sputum findings in asthmatic subjects. Am J Respir Crit Care Med 1998; 157: A609.

29. Peden DB, Boehlecke B, Horstman D, Devlin R. Prolonged acute exposure to $0.16 \mathrm{ppm}$ ozone induces eosinophilic airway inflammation in asthmatic subjects with allergies. J Allergy Clin Immunol 1997; 100: 802-828.

30. Kharitonov SA, O'Connor BJ, Evans DJ, Barnes PJ. Allergen-induced late asthmatic reactions are associated with elevation of exhaled nitric oxide. Am J Respir Crit Care Med 1995; 151: 1894-1899. 